\title{
Legal Analysis of the EU Policy for Sustainable Transport Biofuels
}

\author{
Evgenia Pavlovskaia \\ Law Faculty, Lund University, Sweden \\ *Corresponding Author: evgenia.pavlovskaia@jur.lu.se
}

Copyright $(2014$ Horizon Research Publishing All rights reserved.

\begin{abstract}
The enforcement and implementation of separate aspects of sustainable development and environmental sustainability can be challenging and innovative due to the complexity of this task. Appropriate policy and legal approaches and tools can be needed for this purpose. In this article, the EU experience of developing the framework for sustainable transport biofuels and special structural elements for its enforcement are highlighted and analyzed. The central legal acts in this area, including Directive 2003/30/EC, Directive 2009/30/EC and Directive 2009/28/EC are explored. Advantages and disadvantages of the EU approach to sustainable transport biofuels are discussed. Suggestions for the future development are made. Among them, the ideas to establish an international regime for sustainable transport biofuels are promoted and reflected on. In the work, special focus is laid on the content of Directive 2009/28/EC and the requirements, which it imposes on the EU Member States. The significance of the 2020 binding targets for renewable energy is highlighted, and their possible consequences are discussed. The content of the EU sustainability criteria for biofuels is explained. The cooperation mechanisms and monitoring requirements to the EU Commission and Member States are examined. The EU approach to combine the quantity of the consumed biofuels, which has the form of the binding targets for the EU Member States, and their sustainable quality, expressed as the list of the sustainability criteria, is viewed as efficient and sustainable from an environmental perspective. Though the EU policy for sustainable transport biofuels is still under development and constant improvement, it can be seen as an instructive example of how environmental goals and policy measures can be organized and promoted with the help of binding legal regulations. Certain aspects of the EU approach to sustainable transport biofuels can be efficiently borrowed by other industrial sectors, as well as by other countries that wish to develop a framework for sustainable energy.
\end{abstract}

Keywords Transport Biofuels, EU Binding Targets, Sustainability Criteria, Directive 2009/28/EC, Environmental Law

\section{Introduction}

Warnings about limited oil resources, as well as the necessity to reduce GHG emissions and secure energy supply 1 have become prioritized issues on the EU agenda. It has been suggested to partially replace traditional fossil fuels with other sources of renewable energy, for example with biofuels in the transport sector. This has been seen as a promising solution for complications connected with the extraction and supply of oil, as well as for the reduction of GHG emissions. It has also become understandable that the quality of biofuels and their production methods need to be sustainable. 2 The material, from which biofuels are produced, for example cultivated energy crops, should follow certain sustainability standards. Regulating these issues with the help of sustainability criteria and a legal framework aimed to support the fulfilment of these criteria has been seen as a possible strategy to minimize environmental damage.

\section{Background to the EU Policy for Sustainable Transport Biofuels}

The EU policy for sustainable transport biofuels has a long history and is ambitious. EU has become one of the first

1 The gas crisis in January 2009, when Bulgaria, Slovakia, Greece, Austria, Czech Republic, Slovenia, Hungary, Poland, Romania and Croatia were seriously affected by the cut of the Russian gas supply [European Commission (2009), IP/09/30, The Gas Coordination Group evaluates the current gas crisis and confirms measures to assist countries in need], has shown how vulnerable the EU energy security system is. In 2007, international newspapers wrote that EU is the world's largest importer of oil and gas, importing $82 \%$ of its oil and $57 \%$ of its gas [Associated Press in International Herald Tribune (2007), EU unveils plan to tackle oil and gas dependence; the Heritage Foundation (2007), Europe's Strategic Dependence on Russian Energy]. According to a research from 2007, transport sector in EU depends on oil for $98 \%$ of its fuel needs [the Engineer $(2007)]$. Slovakia, Hungary, Latvia, Poland and Lithuania are all more than $90 \%$ dependent on oil supply from Russia. Greece, Italy, Portugal and Spain are more than $40 \%$ dependent on the oil resources from the Middle East [the European Federation for Transport and Environment (2008), EU spending $€ 1$ billion a day on oil imports as leaders backtrack on efficient cars, Briefing]. Biofuels, particularly in the transport sector, can be seen as one of the possibilities to diminish the EU dependence on the imports of energy sources and to reduce $\mathrm{GHG}$ emissions.

2 Schlegel, S., Kaphengst, T. (2007), European Union Policy on Bioenergy and the Role of Sustainability Criteria and Certification Systems. 
regions, which has developed a legal framework for sustainable transport biofuels. 3 One of the first binding documents in this area came as early as in 1985. It was Directive 85/536/EEC on crude-oil savings through the use of substitute fuel components in petrol, which was subsequently replaced by Directive 2003/17/EC that was related to the quality of petrol and diesel fuels.

\subsection{Directive 2003/30/EC on the Promotion of the Use of Biofuels or Other Renewable Fuels for Transport}

One of the major steps in the development of the EU policy for transport biofuels was made in 2003 with the legislation of Directive 2003/30/EC. This Directive, informally called the Biofuels Directive, contained nine articles and aimed to promote the use of biofuels and other renewable fuels for transport.

Directive 2003/30/EC had a long-lasting influence on the policy for transport fuels in the EU Member States. The Directive's aim, specified in Article 1, was to promote the use of biofuels or other renewable fuels, e.g. renewable-based hydrogen, to replace diesel or petrol for transport purposes. It also expressed an intention to contribute to the fulfilment of such objectives as to meet climate change commitments, maintain environmentally friendly security of supply and promote renewable energy sources.

The Directive contained a list of definitions of different types of fuels that were to be considered as biofuels. Ten sorts were named, including bioethanol, biodiesel, biomethanol and biohydrogen. 4 Biofuels were defined as liquid or gaseous fuel for transport produced from biomass. 5 Biomass had a definition of the biodegradable fraction of products, wastes and residues from agriculture, forestry and related industries, as well as the biodegradable fraction of industrial and municipal waste. 6

One of the most important aspects in Directive 2003/30/EC was that it introduced indicative, non-binding targets, requiring the Member States to set an interim indicative target for 2005 of $2 \%$ of biofuels, and an indicative target for 2010 of 5,75\% of all petrol and diesel for transport placed on the market. 7 No individual targets for separate Member States were specified. A system of strong mandatory targets was considered in the first proposal of the Directive in 2002, but a decision on its adoption was deferred to see whether indicative targets could be achieved. 8

\footnotetext{
3 Other prominent examples are US and Brazil.

4 Article 2.2. Other definitions of the terms, necessary for the understanding of the Directive, were given in Article 2.1.

5 Article 2.1.a.

6 Article 2.1.e.

7 Article 3.1; Jansen, J, Uyterlinde, M. (2004), A fragmented market on the way to harmonisation? EU policy-making on renewable energy promotion, p. 99; Ryan, L., Convery, F., Ferreira, S. (2006), Stimulating the Use of Biofuels in the European Union: Implications for Climate Change Policy, p. 3185; Kanellakis, M., Martinopoulos, G., \& Zachariadis, T. (2013). European energy policy - A review, p. 2.

8 Lucia, D., L., Nilsson, L., J. (2007), Transport biofuels in the European Union: The state of play, p. 535.
}

To be counted for the achievement of the interim targets, biofuels can be produced as:

- pure biofuels or at high concentration in mineral oil derivatives, in accordance with specific quality standards for transport applications;

- biofuels blended in mineral oil derivatives, in accordance with the appropriate European norms, describing the technical specifications for transport fuels (EN 228 and EN 590);

- liquids derived from biofuels, such as ETBE (ethyl-tertio-butyl-ether), where the percentage of biofuel was as specified in definitions in Article 2.9

To promote consumption of biofuels or other renewable fuels, the Member States were able to use policy instruments and measures that best fit their national conditions and domestic interests in respect of all EU regulations. 10 Failure to meet the indicative targets required the Member States to explain the discrepancy on the basis of motivations presented in Article 4.1. With other words, the Member States could legitimately differentiate from the indicative targets of the Directive, if suitable argumentation was presented.11

The Member States were required to monitor the effect of the use of biofuels in diesel blends above $5 \%$ by non-adapted vehicles, 12 and to ensure that information was given to the public on the availability of biofuels and other renewable fuels. 13 The Member States were also recommended to consider the overall climate and environmental balance of the various types of biofuels and other renewable fuels. Priority might be given to the promotion of biofuels, which showed a very good cost-effective environmental balance, while taking into account competitiveness and security of supply. 14

Directive 2003/30/EC presented regulations on the Member States' reporting obligations. 15 The Member States were to submit annual biofuel progress reports to the Commission. The reports had to contain information about such issues as the measures taken to promote the use of biofuels, the national resources allocated to the production of biomass for energy uses other than transport, as well as the total sales of transport fuels and the share of biofuels.

Further, the Member States should submit evaluation reports to the Commission every two years. As a minimum requirement, these reports had to cover national issues regarding cost-effectiveness of the measures taken to promote the use of biofuels and other renewable fuels, the economic aspects and the environmental impact of further increasing the share of biofuels and other renewable fuels, and the life-cycle perspective of biofuels and other renewable fuels. The evaluation reports had also to contain

\footnotetext{
9 Article 3.2

10 According to the grounds of the EU law; see also Howes (2010), Directive 2009/28/EC, p. 122; Lucia, D., L., Nilsson, L., J. (2007) Transport biofuels in the European Union: The state of play, p. 533.

11 Lucia, D., L., Nilsson, L., J. (2007), Transport biofuels in the European Union: The state of play, p. 533.

12 Article 3.3.

13 Article 3.5 .

14 Article 3.4

15 Article 4.
} 
information about the sustainability of crops used for the production of biofuels, particularly land use, degree of intensity of cultivation, crop rotation and use of pesticides, the assessment of the use of biofuels and other renewable fuels with respect to their differentiating effects on climate change and their impact on $\mathrm{CO} 2$ emission reductions and a review of further more long-term options concerning energy efficiency measures in transport. 16

\subsection{Development after Directive 2003/30/EC}

The interim indicative target in Directive 2003/30/EC, which required $2 \%$ of biofuels by 2005 , was not fulfilled. Growth in renewable energy for transport was dominated by a few Member States. Between 2000 and 2006, only Denmark, the Czech Republic, Germany, Slovakia and Hungary increased their shares of renewable energy by more than $2 \% .17$ In 2005, the average use of biofuels counted to $1 \%$ of transport fuel. 18 According to the Commission, the main reasons for the failure to reach the indicative target were the lack of a coherent and effective policy framework throughout EU with a firm long-term vision and the increase in energy consumption. 19

Other reasons for the weak implementation could be an uncertain connection between the policy means, i.e. biofuel consumption and the policy objectives. 20 It is possible that the Member States did not feel compelled to transpose the targets. 21 What is more, differences in how the Member States interpreted the objectives, with emphasis on supply security contrary to interest in self-sufficiency and in the weight different Member States put on the objectives, could be observed. 22

It became clear that the framework for the promotion of biofuels and renewable energy for transport needed improvement, not least in the form of setting a new timeframe. The merely indicative national targets in Directive 2003/30/EC provided uncertain investment environment. The Commission therefore proposed a new, more rigorous framework to drive forward the development of renewable energy and more solid, legally binding targets for 2020.23

In 2006, the Commission published a detailed EU Strategy for Biofuels 24, where the role that biofuels for transport as

\section{Article 4.2 .}

17 Howes T. (2010), Directive 2009/28/EC, p. 122.

18 COM (2009) 192 final, The Renewable Energy Progress Report, Communication from the Commission.

19 COM (2006) 545 final, Action plan for energy efficiency: realising the potential, Communication from the Commission; de Alegría Mancisidor, I. M., Díaz de Basurto Uraga, P., Martínez de Alegría Mancisidor, I., \& Ruiz de Arbulo López, P. (2009), European Union's renewable energy sources and energy efficiency policy review: The Spanish perspective, p. 103; Gullberg, A., T. (2011), The European Union renewable directive: The policy-making process and the stakeholders'positions, p. 4.

20 Lucia, D., L., Nilsson, L., J. (2007), Transport biofuels in the European Union: The state of play, p. 540.

21 Lucia, D., L., Nilsson, L., J. (2007), Transport biofuels in the European Union: The state of play, p. 541.

22 Lucia, D., L., Nilsson, L., J. (2007), Transport biofuels in the European Union: The state of play, p. 541.

23 COM (2009) 192 final, The Renewable Energy Progress Report, Communication from the Commission.

24 COM (2006) 34 final, An EU Strategy for Biofuels, Communication alternative fuels could play in the future was defined. The document also proposed measures to promote the production and use of biofuels. 25 It became an important step in a long-going updating of Directive 2003/30/EC and the development of a more efficient EU policy for biofuels. Further EU publication, relevant for transport biofuels, came in 2007, with the title Renewable Energy Road Map26. This document proposed a biding target of $20 \%$ for the use of renewable energy and $10 \%$ for the share of biofuels in the transport sector by 2020. The Road Map considered biofuels as a potential mechanism, through which lifetime emissions could be reduced. Creation of a separate fuel blend was suggested, with a consequent amendment of Directive 98/70/EC on fuel quality, to allow higher percentages of biofuels in petrol and diesel. Importance to ensure that the used biofuels would be sustainable, both inside and outside EU, was emphasized.

The development of the EU policy on biofuels for transport continued in early 2007 with the communication from the Commission of an Energy Policy for Europe 27. This document dealt with issues of energy, sustainability, industrial development and climate change in a more holistic way. The need for a coordinated promotion of biofuels throughout the EU was underlined. According to the document, the EU should engage third countries and their producers to achieve biofuel sustainability. The Commission, in its turn, would continue and intensify the use of renewable energy through other policies and flanking measures with the aim of creating a real internal market for renewables in EU.28

At the moment of writing, the EU policy for transport biofuels is primarily reflected in Directive 2009/28/EC and Directive 2009/30/EC, which are the central binding documents in this area. Directive 2009/28/EC sets binding targets for the use of biofuels in the transport sector, that each Member State shall achieve by 2020, and outlines obligatory criteria for sustainable biofuels. Directive 2009/30/EC regulates the quality of fuels. The list of the sustainability criteria from Directive 2009/28/EC is repeated in Directive 2009/30/EC almost identically. Because of that and as the structure that supports the enforcement and implementation of the sustainability criteria is more elaborated in Directive 2009/28/EC, my research is mostly based on the regulations from this legal act.

\section{Directive 2009/30/EC on the Quality of Transport Fuels}

\author{
Significant progress in vehicle technology, and the
}

from the Commission.

25 COM (2006) 34 final, An EU Strategy for Biofuels, Communication from the Commission, p. 7 .

26 COM (2006) 848 final, Renewable Energy Road Map. Renewable energies in the $21^{\text {st }}$ century: building a more sustainable future, Communication from the Commission.

27 COM (2007) 1 final, An Energy Policy for Europe, Communication from the Commission.

28 COM (2007) 1 final, An Energy Policy for Europe, Communication from the Commission, p. 14. 
development and better availability of biofuels, urged the revision of the specifications for fuel quality contained in Directive 98/70/EC. The result was a new Fuel Quality Directive (2009/30/EC) that considered petrol, diesel and biofuels, and introduced a mechanism to monitor and reduce GHG emissions. This Directive has very much in common with Directive 2009/28/EC, and was adopted during the same period in April 2009. The aim of Directive 2009/30/EC is to reduce the emission of air pollutants released from transport fuels, and to facilitate the achievement of the EU's 2020 target for transport. The Member States had to transpose Directive 2009/30/EC into national legislation by 31 December 2010.

Article 1 states the scope of Directive 2009/30/EC, which, in respect of road vehicles and non-road mobile machinery, agricultural and forestry tractors, gives technical specifications on health and environmental grounds for fuels, as well as sets a target for the reduction of life cycle GHG emissions. Article 2 provides definitions of the central terms that are used in the Directive including the expressions "life cycle GHG emissions", "GHG emissions per unit of energy" and biofuels. The term biofuels has the same meaning as in Directive 2009/28/EC.29 The terms bioliquids and biomass are not defined. "A supplier" means in the Directive the entity responsible for passing fuel or energy through an excise duty point or, if no excise is due, any other relevant entity designated by a Member State. 30

One of the central articles in the Directive is Article 7.a, which concerns the reductions of GHG emissions. According to it, the Member States shall designate suppliers, responsible for monitoring and reporting life cycle GHG emissions per unit of energy from fuel and energy supplied. From 1 January 2011, suppliers shall report annually to the authorities in the Member States on the GHG intensity of fuel and energy supplied in each Member State. Suppliers shall provide the minimum information about the total volume of each type of fuel or energy supplied, indicating its origin and life cycle GHG emissions per unit of energy. Article 7.a (point 2) also regulates that the Member States shall require suppliers to reduce gradually life cycle GHG emissions per unit of energy from fuel and energy supplied by up to $10 \%$ by December 2020 . The Member States may require suppliers, for this reduction, to comply with the following intermediate targets: $2 \%$ by 31 December 2014 and $4 \%$ by 31 December 2017. To add to this, the reduction shall include indicative additional targets of $2 \%$ by 31 December 2020. Since the fuel producers are free to choose how the targets are achieved, it is expected that the demand for biofuels with a "good-for-the-environment" GHG balance could increase. 31

Life cycle GHG emissions from biofuels shall be calculated in accordance with Article 7.d, which contains the same calculation methodology as Article 19 and Annex V in

29 Article 2.a.ii.9, Directive 2009/30/EC

30 Article 2.a.ii.8.

31 Majer, S., Mueller-Langer, F., Zeller, V., Kaltschmitt, M. (2009), Implications of biodiesel production and utilization on global climate - A literature review, p. 753.
Directive 2009/28/EC. The Member States shall provide suppliers with an opportunity to meet the reduction obligations jointly.

To add to Article 7.d, there are several other Articles in Directive 2009/30/EC that regulate similar issues as Directive 2009/28/EC and have almost identical content. The only significant difference is that Articles in Directive 2009/30/EC refer to biofuels, and Directive 2009/28/EC considers both biofuels and bioliquids. In such a way, Article 7.b in Directive 2009/30/EC, which defines sustainability criteria for biofuels, corresponds to Article 17 in Directive 2009/28/EC, which defines sustainability criteria for biofuels and bioliquids. Article 7.c in Directive 2009/30/EC, which deals with control of the fulfilment of the sustainability criteria for biofuels, corresponds to Article 18 in Directive 2009/28/EC that regulates the same issue. Article 7.e with the title "Implementing measures and reports, concerning the sustainability of biofuels", partially has the same content as Article 20 in Directive 2009/28/EC, but is broader, as it also regulates the EU Commission's reporting obligations to the European Parliament and the Council.

More detailed rules on the reporting obligations of the Commission can be found in Article 9 in Directive 2009/30/EC, which states that by December 2012, and every three years after that, the Commission shall submit a report to the European Parliament and the Council. The report shall be accompanied, where appropriate, by a proposal for amendments. The report shall contain data about the feasibility of increasing the maximum permitted biofuel content of petrol and diesel, the total volume of components used in petrol and diesel, the EU policy on $\mathrm{CO} 2$ emissions from road transport vehicles, and the consequences of the GHG reduction target for the emissions trading scheme. The need for adjustments in the Directive in order to assess possible contributions for reaching the 2020 target for transport shall also be included.

By 2014, the Commission shall submit another report about the achievement of the GHG emission target for 2020, as it is formulated in Article 7.a. If appropriate, modification of the target shall be discussed.

\section{Directive 2009/28/EC on the Promotion of the Use of Energy from Renewable Sources}

In January 2008, the EU Commission proposed a new draft Directive on the promotion of renewable energy. In the course of negotiations, environmental concerns about the production of biofuels were significant. The need to develop efficient sustainability standards for biofuels and to reflect on possible consequences of the biofuel policy was emphasized. The influence of the biofuel policy on food security and possible GHG emission savings from biofuels were discussed much. Other concerns were about the impact on competition for land, the use of water and land resources 
and on possible loss of biodiversity.32 Resulting Directive 2009/28/EC, also called the Renewable Energy Directive, was formally adopted in April 2009. In some aspects it was less ambitious than its draft.

The most prominent innovations in Directive 2009/28/EC, which is central in the present EU framework for transport biofuels, can be formulated as follows:

- It sets mandatory national targets for renewable energy shares, including $10 \%$ of renewables for transport share, in 2020 (Article 3);

- It requires National Renewable Energy Action Plans (Article 4);

- It establishes cooperative mechanisms between the Member States, as well as the Member States and third countries (Articles 7-11);

- It strives to reduce administrative and regulatory barriers (e.g. Article 13), and to improve the provision of information and training (e.g. Article 14); and

- It makes initial steps in promoting sustainability criteria for biofuels (Article 17).

\subsection{The Scope of Directive 2009/28/EC and its Definitions}

The intention of Directive 2009/28/EC is to establish a common framework for the promotion of energy from renewable sources. The Directive sets mandatory national targets for the overall share of energy from renewable sources in gross final consumption of energy, as well as mandatory national targets for the share of energy from renewable sources in transport. It establishes sustainability criteria for biofuels and bioliquids. 33

Definitions of concepts that are applied in the Directive include definitions of different types of energy, biomass, biofuels, bioliquids and guarantee of origin.34 Biofuels are defined as liquid or gaseous fuel for transport produced from biomass. 35 Bioliquids have a definition of liquid fuel for energy purposes other than for transport, including electricity and heating and cooling, produced from biomass. 36 Biomass is defined as the biodegradable fraction of products, wastes and residues from biological origin from agriculture, forestry and related industries including fisheries and aquaculture, as well as the biodegradable fraction of industrial and municipal waste. 37 Biofuels have the same definition as in earlier Directive 2003/30/EC. The definition of biomass is more detailed in comparison to the earlier legislation. Bioliquids were not defined in Directive 2003/30/EC.

From the perspective of this research, the legal definitions are important for understanding, which technical products are regarded as biofuels. The central issues of Directive

32 Howes, T. (2010), Directive 2009/28/EC, p. 140.

33 Article 1.

34 Article 2.

35 Article 2.i.

36 Article 2.h

37 Article 2.e.
2009/28/EC, which are relevant for the thesis, are presented below.

\subsection{Binding Targets for the Member States}

The Directive mandates that a $20 \%$ share of final energy consumption 38 in EU must come from renewable sources by 2020.39 Each Member State's contribution is distributed differentially among the Member States, basing on national income, previously installed capacity and potential for the expending of the renewable energy.40 The individual shares in 2005 and the 2020 targets for each Member State can be found in Annex I, part A of the Directive. To take an example, the share of energy from renewable sources in 2005 for Sweden was $39.8 \%$. The 2020 target for renewable energy sources, which Sweden must achieve, is $49 \%$, which is the highest percentage among the Member States. For the UK, the figures are $1.3 \%$ for 2005 and $15 \%$ for 2020 .

Each Member State shall promote and encourage energy efficiency and energy saving.41 The Member States shall introduce measures that are designed to ensure that the share of energy from renewable sources equals or exceeds that shown in the indicative trajectory set out in Annex I, part B.42

Regulations in Article 3.4 of the Directive are especially important for my research. They mandate that each Member State shall achieve a $10 \%$ share for renewables in the transport sector by 2020. In meeting this target, considerable emphasis is put on the role of biofuels. The $10 \%$ target in the transport sector has been set at the same level for each Member State. This has been done in order to ensure consistency in transportation fuel specifications and availability.43 Member States that do not have the relevant resources to produce biofuels are encouraged to obtain renewable transport fuels from elsewhere, 44 for example importing them from third countries.

Both the $20 \%$ and $10 \%$ EU targets are of a minimum

38 Scarlat, N., Dallemand, J. F., \& Banja, M. (2013). Possible impact of 2020 bioenergy targets on European Union land use. A scenario-based assessment from national renewable energy action plans proposals, p. 596; the concept "final energy consumption" includes the energy commodities delivered for energy purposes to industry, transport, households, services including public services, agriculture, forestry and fisheries, including the consumption of electricity and heat by the energy branch for electricity and heat production and including losses of electricity and heat in distribution and transmission (Article 2.f, Directive 2009/28/EC). The calculation of the 2020 target in terms of final energy consumption can be explained by the willingness to be consistent with the existing legislative arrangements in EU [Howes T. (2010), Directive 2009/28/EC, p. 127].

39 Article 3.1 ; among the main purposes of this mandatory target, there is to provide certainty for investors and to encourage technological development allowing for energy production from all types of renewable sources. To ensure that this mandatory target is achieved, each Member State has to follow an indicative trajectory towards the achievement of their individual national targets (point 14, the Preamble); more information can be found at the European Biofuels Technology Platform, http://www.biofuelstp.eu/, last visited 23-09-2013.

40 De Vita, A., de Coninck H., McLaren, J., Cochran, J. (2009), Climate for Collaboration: Analysis of US and EU Lessons and Opportunities in Energy and Climate Policy, p. 23.

41 The last sentence of Article 3.1

42 Article 3.2.

43 Haga, A., Rabben, J. (2010), Norway: EU Renewable Policy and Legislative Developments.

44 Point 16, the Preamble; see also the European Biofuels Technology Platform, http://www.biofuelstp.eu/, last visited 23-09-2013. 
character. 45

\subsection{Calculation Methods for the Binding Targets}

Biofuels and bioliquids, which do not fulfil the sustainability criteria set out in the Directive, shall not be taken into account, when the final consumption of energy from renewables is calculated.46 The energy content of the transport fuels listed in Annex III shall be taken as it is expressed there. 47 For bioethanol, energy content by weight is $27 \mathrm{MJ} / \mathrm{kg}$, and energy content by volume is $21 \mathrm{MJ} / 1$. The corresponding parameters for biodiesel are $37 \mathrm{MJ} / \mathrm{kg}$ and 33 $\mathrm{MJ} / 1$, for traditional petrol $43 \mathrm{MJ} / \mathrm{kg}$ and $32 \mathrm{MJ} / \mathrm{l}$, and for traditional diesel $43 \mathrm{MJ} / \mathrm{kg}$ and $36 \mathrm{MJ} / \mathrm{l}$.

For the purposes of demonstrating compliance with national renewable energy obligations and the target for the use of energy from renewable sources for transport, the contribution made by biofuels produced from wastes, residues, non-food cellulosic material and ligno-cellulosic material shall be considered to be twice that made by other biofuels. 48 The Directive does not contain definitions of "waste" and "residues". The Commission considered that these concepts should be interpreted in line with the objectives of Directive 2009/28/EC. 49 There is an explanation from the preparatory works that waste, in this context, can be understood as any substance or object, which the holder discards or intends or is required to discard, including materials that have to be withdrawn from the market for health or safety reasons. Raw materials that have been intentionally modified to count as waste (e.g. by adding waste material to a material that has not been waste), should not be considered as qualifying for the $10 \%$ binding target. 50

The initiative to count biofuels produced from wastes, residues, non-food cellulosic material and ligno-cellulosic material double can be explained by environmental benefits, which these production materials have, in comparison to biofuels produced from crops of an agricultural origin.

\subsection{Cooperation Mechanisms for the Achievement of the Binding Targets}

There are three elements of cooperation mechanisms in the Directive: statistical transfers between the Member States (Article 6), joint projects between the Member States (Articles 7 and 8), and between the Member States and third countries (Articles 9 and 10), and joint support schemes (Article 11).

Statistical transfers are based on agreements between the Member States to transfer a quantity of renewable energy produced in one Member State to another Member State for

45 European Commission, Mobility and Transport, Clean Urban Transport; European Commission, Strategic Energy Technologies Information System SETIS (2013), Biofuels.

46 Article 5.1, 3.d line.

47 Article 5.5.

48 Article 21.2.

49 Communication (2010/C 160/02), p. 5.2.

50 Communication $(2010 / \mathrm{C} 160 / 02)$, p. 5.2 the purpose of target achievement. The transfer is virtual, and it does not require accompanying energy flow. 51 The transfer shall not affect the achievement of the national target of the Member State making the transfer.52 The transfer opportunity exists so that the Member States with significant renewable energy sources, or with effective support schemes, can offer spare renewable energy to other Member States. It is expected that transfer agreements would be made for several years. 53

Joint projects between the Member States are also promoted by the Directive. 54 The Member States may cooperate on all types of joint projects relating to the production of electricity, heating or cooling from renewable energy sources. Private operators may be involved in this cooperation. 55 The Member States shall notify the Commission about the amount of electricity, heating or cooling from renewable energy sources produced by any joint project in their territory, which became operational after 25 June 2009, or by the increased capacity of an installation that was refurbished after that date. 56

In practice, a joint project may cover a broad spectrum of actions, including building or co-financing of infrastructure or even an energy purchase agreement. The intention behind the mechanism is the same as for statistical transfers, namely to facilitate renewable energy production and sharing of the resulting energy towards two or more Member States' national targets, with the final aim to reduce the overall cost of reaching the 2020 targets. 57

According to the regulations of joint support schemes, 58 the Member States may agree to join or coordinate their national support schemes (e.g. a common feed-in tariff or green-certificate regime 59). Under certain conditions, expressed in the Directive, some amount of energy from renewable sources produced in the territory of one participating Member State may count towards the national overall target of another participating Member State.

The central idea of the cooperation mechanisms is for the Member States to fulfil part of the 2020 binding targets in another country by providing financial support, with the potential advantage of accessing cheaper production of renewable energy in other countries. 60 The Preamble encourages the Member States to pursue all appropriate forms of cooperation in relation to the objectives set out in Directive 2009/28/EC.61 Compatibility of the cooperation mechanisms from Directive 2009/28/EC with the EU competition law is an issue that requires further investigation. However, it lies outside the central focus of this research.

Most Member States have continued to focus on national

51 Howes, T. (2010), Directive 2009/28/EC, p. 133.

52 Article 6.

53 Howes, T. (2010), Directive 2009/28/EC, p. 133.

54 Articles 7 and 8.

55 Article 7.1.

56 Article 7.2.

57 Howes, T. (2010), Directive 2009/28/EC, p. 133.

58 Article 11.

59 Howes, T. (2010), Directive 2009/28/EC, p. 133.

60 Kanellakis, M., Martinopoulos, G., \& Zachariadis, T. (2013). European energy policy - A review, p. 3.

61 Point 35, the Preamble. 
resources to achieve their 2020 targets on their own. They have not sought to reduce costs by developing cheaper resources in other parts of the single market. 62

Beyond the named possibilities for cooperation, a medium to long term EU cooperation strategies can be developed, in order to make the energy sector function cost efficiently. 63

\subsection{Sustainability Criteria for Transport Biofuels}

The sustainability criteria for biofuels, which have not been set for other issues than environmental sustainability, are presented in Article 17 of Directive 2009/28/EC. They are relevant for all types of biofuels, both liquid and gaseous, as well as for bioliquids used for other energy purposes than transport. Four types of the sustainability criteria from Article 17 can be distinguished:

1. biofuels shall achieve a minimum level of GHG savings, (carbon stock losses from land use change are not to be included in this calculation), Article 17.2;

2. land with high biodiversity shall not be converted for biofuel production, Article 17.3;

3. land with high carbon stocks shall not be converted for biofuel production, Article 17.4; and

4. land that was peatland in January 2008 shall not be used for the production of raw materials for biofuels, Article 17.5.

Only biofuels that fulfil the sustainability criteria from Article 17 can be counted for the achievement of the $10 \%$ of renewable energy goal in the transport sector.64 The same is about receiving financial support for the consumption of biofuels: it can only be given for biofuels, which fulfil the sustainability criteria of Article 17. This is stated in Article 17.1. The sustainability criteria are applicable equally to domestically produced and imported biofuels. 65 This implies that biofuels can be imported into EU, even if they do not meet the sustainability criteria, but compliance is required in order for biofuels to count towards the achievement of the EU or national renewable energy obligations, or to be eligible for financial support.

Biofuels produced from waste and residues, other than agricultural, aquaculture, fisheries and forestry residues, need only fulfil the sustainability criterion set out in Article 17.2 , i.e. the requirements for GHG emission savings, in order to be taken into account for the above named purposes. 66 This condition can be explained by the fact that other sustainability criteria in Article 17, due to their nature, are not directly applicable on biofuels that are produced from waste and residues. This also indicates that different types of

62 COM (2011) 31 final, Renewable Energy: Progressing towards the 2020 target, Communication from the Commission, p. 11.

$63 \mathrm{COM}$ (2011) 31 final, Renewable Energy: Progressing towards the 2020 target, Communication from the Commission, p. 11.

64 Article 17.1.

65 This idea is expressed in COM (2008) 30, 2020 by 2020 Europe's Climate Change Opportunity, Communication from the Commission; Afionis, S., Stringer, L., C. (2012), The European Union leadership in biofuels regulation: Europe as a normative power?

66 Article 17.1. biofuels would need different sustainability criteria, depending on the production material.

Article 17.2 of Directive 2009/28/EC regulates the first type of the EU sustainability criteria, which contains requirements for GHG emission savings, in comparison to traditional fossil fuels, stating that the savings shall be at least $35 \%$, rising to $50 \%$ from 2017 . Calculation methods for this sustainability criterion are presented in Article 19.1.67 These methods can be viewed as a tool to measure and control the fulfillment of the first sustainability criterion.

The second type of the EU sustainability criteria is formulated in Article 17.3, which focuses on biodiversity protection. The paragraph defines areas, from which raw materials for the production of biofuels are not to be originated. These areas, considered as "highly diverse", cover primary forests and other wooded land with no indication of human activity, as well as areas designated for nature protection purposes. It is also not permitted to take into account raw materials from areas, which protect rare, threatened or endangered eco-systems. An exception is provided for materials taken from land, in relation to which it can be shown that the production of biofuel feedstocks has not interfered with conservation efforts. Raw materials taken from highly diverse grassland are also prevented from being used to meet the 2020 targets. On the basis of these definitions, indicators can be created for the assessment of how this sustainability criterion is fulfilled.

Article 17.4 contains the third type of the EU sustainability criteria, which is aimed to protect areas that in January 2008 or after it were with high carbon stock, such as wetlands and continuously forested areas. Raw materials for the production of biofuels are not to be originated from these types of land either.

Article 17.5 formulates the fourth and the last type of the EU sustainability criteria, which has the purpose to protect land that was peatland in January 2008, due to its high carbon value, unless there is evidence that the cultivation of that raw material does not involve drainage of previously undrained soil. Some researchers distinguish only three types of the EU sustainability criteria for transport biofuels, meaning that the issue about land that was peatland should not be addressed separately.

The requirements in Article 17.6 that address the so-called agro-environmental practices contain norms for agricultural raw materials that are cultivated in EU and used for the production of sustainable biofuels. 68 Unlike the majority of the sustainability criteria, verification of compliance for this criterion is not addressed in Directive 2009/28/EC.69 The Member States should apparently rely on their national control systems for ensuring that farmers fulfil these requirements. 70 The intention with the regulation in Article

67 Afionis, S., Stringer, L., C. (2012), The European Union leadership in biofuels regulation: Europe as a normative power?

68 These raw materials shall be obtained in accordance with the requirements and standards referred to in Council Regulation (EC) No $73 / 2009$.

69 Article 18.1.

70 Commentaries on this criterion are from Communication (2010/C 160/02), p. 2.1 . 
17.6 is that it would facilitate the establishment of common rules for direct support schemes for farmers under the common agricultural policy.

Due to the fact that the sustainability criteria have been adopted according to Article 95 of the EC Treaty, which contains internal market regulations, a Member State cannot on other sustainability grounds than those presented in Article 17 refuse to take into account biofuels for the purposes that are named in Article 17.1, i.e. the achievement of the 2020 renewable energy targets or a possibility for financial support.71 With other words, a Member State does not have the right to establish stricter sustainability criteria for this purpose.

The Commission may also recognize areas for the protection of rare, threatened or endangered ecosystems, or species recognized by international agreements or included in lists drawn up by intergovernmental organizations or the International Union for the Conservation of Nature. The Commission may decide that land that falls within the scope of a national or regional recovery program, aimed at improving severely degraded or heavily contaminated land, should fulfil the criteria referred to in point 9 of part $C$ of Annex V.72 These criteria, or rather definitions, are:

a) "severely degraded land" means land that for a significant period of time, has either been significantly salinated or presented significantly low matter content and has been severely eroded; and

b) "heavily contaminated land" means land that is unfit for the cultivation of food and feed due to soil contamination (Annex V, part C, point 9).

\subsection{Monitoring: Providing Transparency and Information to Public}

Monitoring plays an important role in the EU framework for transport biofuels. According to the explanations in the Preamble, the Commission should monitor the supply of the EU market for biofuels. 73 It is appropriate to monitor the impact of biofuel cultivation, such as through land-use changes, including displacement, the introduction of invasive alien species and other effects on biodiversity, and effects on food production and local prosperity. 74

Among monitoring measures expressed in Directive 2009/28/EC, there are requirement of transparency to the public of certain information 75 and the obligation to provide information.76 It is underlined in the Preamble that it is necessary to set transparent and unambiguous rules for calculating the share of energy from renewable sources and for defining these sources. 77

As an additional issue, Directive 2009/28/EC requires the Member States to closely monitor the impacts of biofuel

71 Article 17.8 .

72 Article 18.4

73 Point 16, the Preamble.

74 Point 78, the Preamble.

75 Article 24.

76 Articles 14 and 21.

77 Point 11, the Preamble. consumption and to explore the application of sustainability criteria for biomass in general, which can be seen as a positive initiative for the promotion of sustainable biofuels.

To follow the transparency requirement, the Commission shall establish an online public Transparency Platform. This Platform shall serve to increase transparency and facilitate and promote cooperation between the Member States. 78 The Commission shall particularly make public information about the Member States' National Renewable Energy Action Plans, Member States' national reports, 79 and the Commission reports. 80 Where necessary, the confidentiality of commercially sensitive information shall be preserved. 81

At present, the Transparency Platform of the Commission can be found at http://ec.europa.eu/energy/renewables/transparency_platfor $\mathrm{m} /$ transparency platform en.htm. 82 It contains different documents of the Member States and the Commission, including the Commission's progress reports on the Member States' advancement in achieving the targets for renewable energy, the Member States' Action Plans, the Commissions reports on the implementation of different Articles of the Directive and other related documents.

The Member States shall ensure that information on support measures is made available to all relevant actors, including consumers, builders, installers and suppliers. 83 The Member States, with the participation of local and regional authorities, shall develop suitable information, awareness-raising guidance or training programs, in order to inform citizens of the benefits and practicalities of developing and using energy from renewable sources. 84

The Member States shall ensure that information is given to the public on the availability and environmental benefits of all different renewable sources of energy for transport. When the percentages of biofuels, blended in mineral oil derivatives, exceed $10 \%$ by volume, the Member States shall require this to be indicated at the sales points. 85 The Member States are not prohibited from making information about sustainable biofuels public. 86

\subsection{Other Relevant Regulations in Directive 2009/28/EC}

Article 20 in Directive 2009/28/EC refers to supplementations that should be made to the Directive's regulations on the sustainability criteria, and that these supplementations shall take into consideration regulations in Directive 2009/30/EC about fuels quality. A clear connection between Directive 2009/28/EC and Directive 2009/30/EC can be observed.

The Member States shall clearly define technical

78 Article 24.1.

79 Referred to in Article 22.

80 Referred to in Article 23.3.

81 Article 24.

82 The web-site was visited last 23-09-2013.

83 Article 14.1.

84 Article 14.6.

85 Article 21.1.

86 Communication (2010/C 160/02), p. 2.5. 
specifications 87 that must be met by renewable energy products and equipment, in order to benefit from support schemes. Where European standards exist, including eco-labels, energy labels and other technical reference systems established by the European standardization bodies, such technical specifications shall be expressed in terms of those standards. 88

For matters related to the sustainability of biofuels and bioliquids, the Commission shall be assisted by the Committee on the Sustainability of Biofuels and Bioliquids. 89 The Member States shall communicate to the Commission the text of the main provisions of national law, which they adopt in the field covered by the Directive. 90

The Member States may encourage investment in research and development in relation to those and other renewable energy technologies that need time to become competitive. 91

\section{Development after Directive 2009/28/EC}

In 2010, EU adopted a package of two communications and a decision, providing non-binding guidance on the content of the sustainability criteria. 92 Among the recommendations from the Commission, there has been an emphasis on the protection of undisturbed natural areas. The documents have highlighted that biofuels should not be made from raw materials from tropical forests or recently deforested areas, drained peatland, wetland or highly biodiverse areas. Guidelines for assessing this sustainability criterion have been set out, and the conversion of forest for oil palm plantations has been explicitly prohibited. The extent to which this prohibition is legally binding for land owners and biofuel producers outside EU can be discussed. The documents from 2010 have promoted biofuels with high GHG savings further.

According to Communication 2010/C 160/02, the EU sustainability criteria for biofuels would apply equally to domestically produced and imported biofuels. 93

At present, the EU Commission works closely with CEN (the European Committee for Standardization) for the development and continuous improvement of standards. The work, carried out by CEN Technical Committee 383, is to assist economic operators in providing evidence for the provisions relating to the EU sustainability criteria for

87 For example technical specification for such renewable energy products as photovoltaics, solar thermal and heat pumps, the information can be found in ECORYS (2008), Assessment of non-cost barriers to renewable energy growth in EU Member States - AEON, p. 16.

88 Article 13.2.

89 Article 25.2 point 2

90 Article 27.2.

91 Point 89 , the Preamble.

92 Communication $(2010 / \mathrm{C} \mathrm{160/01)}$ on voluntary schemes and default values in the EU biofuels and bioliquids sustainability scheme, Communication (2010/C 160/02) on the practical implementation of the EU biofuels and bioliquids sustainability scheme and on counting rules for biofuels, and Decision C(2010) 3751 on guidelines for the calculation of land carbon stocks.

93 Communication (2010/C 160/02), p. 1. biofuels. CEN Technical Committee 383 consists of experts from the fuel industry, energy suppliers, biofuels producers, certification bodies as well as various stakeholders. The actual CEN/TC 383 Standards are still in their draft form, but can be used by economic operators and the Member States in relation to the sustainability criteria. To take an example, two types of standards can be mentioned:

- prEN 16214-2 on Conformity assessment including chain of custody, which presents work on the implementation of the mass balance method of custody chain management as well as the adequate standard of independent auditing, as set out in respectively Article 18.1 and Article 18.3 of Directive 2009/28/EC, and

- prEN 16214-3 on Biodiversity and environmental impacts, which presents elaboration on the provision of evidence that the production of raw material has not interfered with nature protection purposes (compare with the requirements in Article 17.3.b of Directive 2009/28/EC), that the harvesting of raw material is necessary to preserve grassland's status (compare with the requirements in Article 17.3.c.ii of Directive 2009/28/EC), and that the cultivation and harvesting of raw material does not involve drainage of previously undrained soil (compare with the requirements in Article 17.5 of Directive 2009/28/EC). 94 It should be noted that the Commission has to establish the criteria and geographic ranges to determine which grassland can be considered to be highly biodiverse grassland.

The close connection of the EU sustainability criteria for biofuels with the CEN standards will increase the use and influence of the EU criteria at the international arena. This will also contribute to the harmonization of the existing legal frameworks and voluntary sustainability standards for transport biofuels. The CEN standards can also function as the basis for emerging legal frameworks and sustainability standards, as well as for multilateral and bilateral agreements. 95

Other tendencies for the future are, that the $\mathrm{EU}$ Commission has invited the Member States to implement their National Action Plans, created according to the target setting in Directive 2009/28/EC, and to make infrastructure planning strategies more efficient. At the same time the Commission calls to respect the existing environmental law of EU and, conforming to best practices, develop various cooperation mechanisms. In spite of reforms of the existing national environmental legislations, stability for investors should be guaranteed and retroactive changes should be avoided.96

NGOs might have interest to combine the EU binding

94 European Commission, Biofuels, Sustainability Criteria http://ec.europa.eu/energy/renewables/biofuels/sustainability_criteria_en.ht m; last visited 24-09-2013.

95 Biomass Technology Group, BTG (2008), Sustainability Criteria \& Certification Systems for Biomass Production, p. 91.

96 Communication from the Commission COM (2011) 31 final, Renewable Energy: Progressing towards the 2020 target, pp. $14-15$. 
sustainability criteria with additional voluntary criteria into a very solid voluntary sustainability standard for biofuels. Producing companies might have interest to develop voluntary sustainability standards to meet the market demands created by the EU policy for transport biofuels.97 Collaboration between these groups of actors and research institutes has the potential to improve the quality and implementation of sustainability criteria for biofuels considerably.

\section{Discussion of the EU Policy for Sustainable Transport Biofuels}

The discussion of the EU policy for sustainable transport biofuels consists of two main parts: general reflections on the EU approach to the promotion and support of sustainable transport biofuels, and a more specific discussion of its central legal framework Directive 2009/28/EC. The strong and weak sides of the EU policy for sustainable transport biofuels and Directive 2009/28/EC are analyzed. Suggestions for the future development of the EU policy for sustainable transport biofuels and relevant legislation are provided.

\subsection{General Reflections on the EU Policy for Sustainable Transport Biofuels}

Judging from the material, presented and investigated in the previous sections, the EU policy for sustainable transport biofuels is logical, clear and consequent. A large variety of the EU legal and non-binding policy documents in this area emphasize mainly the same central issues. Among the advantages of transport biofuels in comparison to traditional fossil fuels, it is continuously underlined that biofuels are aimed to reduce GHG emissions, secure energy supply and create new job opportunities. 98 Other positive impacts that the subsequent development of the EU policy for sustainable transport biofuels is expected to have is a long-term stability, which reduces investment risks for the business community and provides rational financial grounds for increased investments, as well as regional development, primarily in rural areas.

In the beginning, the EU policy has only been directed at the quantitative development of biofuels. The stress was put on how much the EU Member States' consumption of biofuels should be. This approach was reflected by imposing quantitative targets for biofuels. Later, attention has been paid to the quality of biofuels: in the Directives from 2009, a set of binding sustainability criteria for biofuels has been presented. The approach, when the quantity of the consumed biofuels is combined with their sustainable quality seems to be efficient from an environmental perspective.

97 Biomass Technology Group, BTG (2008), Sustainability Criteria \& Certification Systems for Biomass Production, p. 92.

98 Di Lucia, L. (2013). Too difficult to govern? An assessment of the governability of transport biofuels in the EU, p. 2 .
Though the EU legal and policy documents in the researched area provide a convincing impression, they generate some critical thinking. For example, while the 2005 quantitative targets for biofuels, formulated in Directive 2003/30/EC have not been achieved, EU has set new stricter targets that are to be achieved by 2020 . It is questionable to what extent this approach is reasonable and useful.

There is an opinion that biofuels as a source of renewable energy are not the only possible solution for the transport sector. Other alternatives can be very promising, such as electricity and hybrid motor vehicles. 99 This approach should be taken into account, particularly because it is not realistic to produce as much biofuels, as are needed to replace all traditional fossil fuels. The EU policy documents should perhaps contain more reflections on the fact that biofuels are not the only possibility for the future. There are other alternatives with a very good potential.

While analyzing the EU legal and policy documents, a broader perspective on how the EU transport sector should look like in the future is missing. The binding targets for the renewable energy for transport have been set, and this has been a considerable step forward. However, the future development of the EU transport sector beyond these targets is also of much importance. Possibly, various developmental models or scenarios should be suggested and discussed.

As it looks like today, it is not economically profitable to cultivate crops of an agricultural origin for the production of biofuels in EU. This means that large amounts of biofuels, which will be used to achieve the EU binding targets, should be imported from other places, e.g. developing countries. This aspect could be stressed and explained more in the EU policy documents. It is questionable, whether EU has the right to set internal environmental goals that to a greater extent depend on export from developing countries. It can happen that developing countries lack technological and other solutions, including legal frameworks, social conditions and infrastructure, required for the sustainable production and export of biofuels. There are risks that a large-scaled production of biofuels can deteriorate ecological systems in developing countries.

When setting the EU targets for renewable energy, it can be reasonable to require that a certain per cent of sustainable transport biofuels is produced inside EU. It can be discussed, whether binding regulations on the production of sustainable and cost-effective biofuels inside EU should be developed. This can be done with the purpose to make the whole production and trade chain of transport biofuels more sustainable. Further research on this question should be done.

In dealing with the challenge of domestic production in $\mathrm{EU}$, hope can be laid on biofuels produced from wastes, residues and non-food cellulosic material. With their help, the percentage of locally produced biofuels can be

99 Börjesson, P., Ericsson, K., di Lucia, L., Nilsson, L., Åhman, M. (2008), Hållbara drivmedel - finns de?, p. 49. 
increased. 100 However, not everything is clear. Firstly, biofuels produced from wastes, residues and non-food cellulosic material are not in mass production they are still in a research phase. 101 At present, there is no better alternative than a large-scaled import of biofuels of an agricultural origin. Secondly, it does not sound sustainable to assume that biofuels produced from wastes, residues and non-food cellulosic material will solve all the problems, which biofuels of an agricultural origin have not been able to solve.

The EU policy for sustainable transport biofuels reflects how EU interprets the concept of sustainability in the area of biofuel industry. 102 Does EU have any ethical right to impose its sustainability concerns on other world states? How will the involved actors, including producers of transport biofuels in developing countries, react to the EU initiatives? Have their opinions been taken into account, when the EU sustainability criteria for transport biofuels have been formulated? All these questions are in demand of subsequent analysis.

Creation of an international regime for sustainable transport biofuels, where all aspects important for the global sustainability and carrying capacity of the Earth's biosphere and ecosystems are taken into consideration, can be a desirable solution. Apparently, the EU policy is not sufficient to establish a transcontinental sustainable production of biofuels. Possibilities to meet bilateral and multilateral agreements between EU and countries that produce biofuels, without coming into conflict with the WTO regulations, should be thought over. 103

The establishment of an international regime for sustainable transport biofuels can be started with the elaboration of soft law principles, relevant for this purpose. Though soft law principles do not per se have binding normative force, they can have much legal relevance.104 The advantage of soft law principles in this situation is that it would not take much time to negotiate and enforce them, in comparison to binding international agreements. The regime formation can involve compulsory and voluntary initiatives with various degrees of public and private participation at different levels. Governing measures, cooperation and input of NGOs, large and small industries and regional representatives are just a few suggestions. 105

100 Scarlat, N., Dallemand, J. F., \& Banja, M. (2013). Possible impact of 2020 bioenergy targets on European Union land use. A scenario-based assessment from national renewable energy action plans proposals, p. 599 . 101 Hoogeveen, J., Faure, J.-M., van de Giessen, N. (2009), Increased Biofuel Production in the Coming Decade: to What Extent Will it Affect Global Freshwater Resources?, p. 152.

102 At present, there is no agreement on what sustainable biofuels actually are, or how they should be promoted [Di Lucia, L. (2013). Too difficult to govern? An assessment of the governability of transport biofuels in the EU. Energy Policy, p. 3].

103 This approach is regulated in Article 9 of Directive 2009/28/EC. Article 9 , as has been explained in the previous Chapter, allows cooperation between the Member States and third countries on all types of joint projects. Though this regulation refers to renewable electricity production, the idea behind it can be used in the promotion of sustainable production of biofuels. Article 18.4 of Directive $2009 / 28 / \mathrm{EC}$ deals with a similar initiative. It states that EU shall endeavor to conclude bilateral or multilateral agreements with third countries containing provisions on sustainability criteria for biofuels. 104 Ebbesson, J. (1996), Compatibility of International and National Environmental Law, p. 142.

105 Similar ideas are expressed in Börjesson, P., Ericsson, K., di Lucia, L.,
The drawback of this approach is that it can be problematic to influence countries with different, sometimes contradictory interests to join an international environmental regime. Another drawback is that even if a desirable number of countries-participants is found, the creation and subsequent development of a regime for sustainable transport biofuels will be a slow process that can take years of negotiations. If this approach is applied, there will possibly be a need for an over-national institution to govern and implement international policies for sustainable biofuels. The work of such an institution can be difficult to organize.

To make the EU policy for sustainable transport biofuels more effective in relation to its purpose, public participation and public awareness about sustainable transport biofuels and their production methods should be increased. Relevant information about different types of transport biofuels and their influence on environment should be distributed to consumers, 106 so that they understand their preferences and choices better. Such measures are important both at the international, regional and national levels.

Summarizing reflections can be made that the EU policy for sustainable transport biofuels should rather be seen as a developing process, not as a static notion. It has its own pros and corns. On the one hand, it is ambitious, consequent and thoroughly planned. It contains a lot of interesting ideas and efficiently functioning elements, which can be borrowed for policies of a similar kind. On the other hand, there are many aspects dealing with the environmental sustainability, which remain unclear. For example, the EU policy relies much on the import of biofuels, or biomass for biofuel production, from countries outside EU, which cannot be viewed as sustainable in the long perspective. The EU policy can win more, if it encourages domestic production of sustainable transport biofuels. The EU initiatives and efforts are probably not enough to create and efficiently govern an international regime for sustainable transport biofuels.

\subsection{Reflections on the Content of Directive 2009/28/EC}

Directive 2009/28/EC plays the central role in the EU policy for sustainable transport biofuels. The most important aspects of its content should be discussed here.

It is explained in the Preamble of the Directive that the 2020 individual targets for the share of renewables in the final energy consumption have been determined with due regard to a fair and adequate allocation, considering the EU Member States' different starting points and potentials. 107 Much can be argued about the advantages and disadvantages of the differentiated target approach. The individual targets are more preferable environmentally, because different Member States have different conditions for the development of renewable energy. The sum of the

Nilsson, L., Åhman, M. (2008), Hållbara drivmedel - finns de?; Ebbesson J. (1996), Compatibility of International and National Environmental Law, p. 32.

106 Börjesson, P., Ericsson, K., di Lucia, L., Nilsson, L., Åhman, M. (2008), Hållbara drivmedel - finns de?, p. 90.

107 Point 15, the Preamble. 
appropriately set individual targets makes it easier to achieve the EU common targets. Still, the percent of renewable energy, which different Member States are to achieve by 2020, varies considerably. It is unclear what possible consequences of such a disproportionate division can be, and how this will influence the development of the EU biofuel industry. Differences in the target setting should not be so radical, perhaps, as this can lead to inadequate consequences and inconsistent effects. Another controversial aspect is whether the $10 \%$ target of the share of renewables in the transport sector should also be differentiated, reflecting individual conditions of each Member State, and what possible effects this can have.

It can be explored whether there is a need to set binding targets for renewable sources of energy in the transport sector at all, and what strong and weak sides this can have. The binding targets provide security for investments and create stability at the market. They can also lead to the lack of flexibility with regard to new technologies and new changing conditions. My opinion is that EU needs binding targets for renewables in the transport sector, where biofuels are estimated to play a dominating role, and this is not only to create security for investments. Biofuels, if produced in a sustainable way, have the potential to contribute to the reduction of GHG emissions and, consequently, to combating climate change. Biofuels are a promising supplement to traditional fossil fuels, which at present are the main source of GHG pollution in EU.

The EU binding targets for renewable energy fulfil the function of an environmental planning, which helps to use natural resources in an efficient and rational way. Firstly, the EU binding targets stir the development of the biofuel market. Secondly, they regulate the quantity of biofuels that are produced, imported to and used in EU. The latter aspect is especially important from the environmental point of view: globally, biofuels should be produced in reasonable amounts that are sustainable for our planet and the carrying capacity of its biosphere. An unreasonable and spontaneous increase in biofuel production can lead to the use of less sustainable production methods. Gradual and well-planned increase, on the contrary, is able to facilitate the realization of the biofuel potential. 108 Thirdly, the binding targets are likely to stimulate the creation of the EU biofuel regime, with the impact on the international biofuel production.

The EU binding targets will certainly promote the use of sustainable biofuels in EU. Among the drawbacks of the binding targets, it can be mentioned that they will interfere with natural market mechanisms. A recommendation can be given that the $10 \%$ target for renewable energy should not be eliminated. It should be probably minimized, in order to be more realistic. Research can be done whether an unsustainable fulfilment of the $10 \%$ target can be destructive for the environment.

Another issue for consideration is that there is a need for an internationally accepted definition or explanation of how

108 Börjesson, P., Ericsson, K., di Lucia, L., Nilsson, L., Åhman, M. (2008), Hållbara drivmedel - finns de?, p. 101. the concepts of sustainable development and sustainability are understood in relation to the production of transport biofuels. A well-formulated definition or explanation will contribute to the clarity and precision of the content of Directive 2009/28/EC, as well as rationalize the understanding of its implementation area.109

It is doubtful whether the production of biofuels made of wastes, residues and non-food cellulosic material is enough promoted in Directive 2009/28/EC. It can be advised that the production of these types of biofuels should be encouraged more, because natural scientists see the future of the biofuel sector in the development of biofuels of this type.

Critical questions that can be raised, with the purpose to safeguard environmental protection are whether Directive 2009/28/EC functions as it has been planned, and whether it leads to the achievement of the determined environmental goals. Assessment of how the Directive prevents environmental degradation is important.

Strong and weak sides of Directive 2009/28/EC should be finally summarized. Starting with the strong sides, Directive 2009/28/EC is a positive legislative initiative in the field of environmental law. It reflects that $\mathrm{EU}$ pays much attention to the environmental and climate issues, as well as continues to develop environmental protection. The EU initiative is very advantageous for the global environment. Legal and political power of EU to preserve environmental interests exceeds what separate EU Member States can do in this area. EU uses this advantage efficiently, being an important environmental actor on the international political arena.

The introduction of a legal framework with sustainability criteria is a large step forward in law. It is a motivating example internationally. The Preamble of Directive 2009/28/EC plays a significant role in providing additional information and explaining the content of this legal act. For example, the importance of the issue of land use change and consequences of the biofuel production for the food market are especially stressed there. This approach can function as an example of how an efficient legal framework can be constructed, though certain structural elements in Directive 2009/28/EC should possibly be elaborated in the future, in order to protect and safeguard sustainability even more.

Directive 2009/28/EC, its $10 \%$ binding target for the transport sector, calculation methods for its achievement, definitions of different types of biofuels, sustainability criteria for biofuels and required monitoring procedures are a good start in promoting sustainable biofuels. It can happen that international obligations are expressed in vague terms, and this creates interpretation and implementation difficulties. 110 This is not the case with Directive 2009/28/EC and the EU policy documents for sustainable transport biofuels. In the Directive, the 2020 targets for the Member States are clearly stated, and the content of the sustainability criteria is transparent. The definitions are clear

109 Similar ideas about the importance of clear definitions have been expressed in Westerlund, S. (2003), Miljörättsliga grundfrågor 2.0, p. 74 .

110 Ebbesson, J. (1996), Compatibility of International and National Environmental Law, p. 134. 
and precise, though their list could be extended. The question whether the sustainability criteria are formulated clear enough for the involved actors to understand and fulfil them can be discussed further.

The analysis of the central issues in Directive 2009/28/EC in relation to the sustainable quality of transport biofuels and their production indicates that setting binding national targets is an important instrument to implement and enforce sustainability in this area. The targets indicate the level, which national energy policies shall achieve, and help to evaluate the efficiency of measures, which the Member States apply.111 The fixed timeframe for the achievement of the targets provides stability for the producing industry and gives assurance to necessary investments, which is a very positive impact.

Pointing out the weak sides of Directive 2009/28/EC, it is vague what environmental effects an increased production of biofuels, promoted by this legal act, will have. It can be argued whether there is a need to set interim sub-targets for renewable energy in the transport sector, with the purpose to simplify the achievement process for the EU Member States. In spite of the fact whether and how EU develops its policy for sustainable transport biofuels, a strong tendency is that the use of biofuels will be expanded internationally, particularly in developing countries. 112 The elaboration of the sustainability criteria for biofuels should be continued, in order to promote their sustainable quality and establish a minimum level of environmental protection during their production.

\section{Conclusions}

In this article, the EU policy for sustainable transport biofuels, its development and main issues have been investigated. The content of the central legal frameworks in this area, including Directive 2003/30/EC, Directive 2009/30/EC and Directive 2009/28/EC have been explored. The obligations, which these documents have imposed on the EU Member States, have been considered. Special focus has been laid on the content of Directive 2009/28/EC, which takes the central place in the EU policy for sustainable transport biofuels. A number of structural elements, important for the efficient functioning of Directive 2009/28/EC, have been outlined. Among them there are the binding targets for renewable energy, which the EU Member States need to achieve; calculation methods for the binding targets; cooperation mechanisms, allowed and recommended for the achievement of the binding targets; sustainability criteria for transport biofuels, necessary for the achievement of the binding targets; and monitoring of how the requirements of Directive 2009/28/EC are fulfilled. Possibilities to establish an international regime for

111 Lucia, D., L., Nilsson, L., J. (2007), Transport biofuels in the European Union: The state of play, p. 535.

112 Börjesson, P., Ericsson, K., di Lucia, L., Nilsson, L., Åhman, M. (2008), Hållbara drivmedel - finns de?, p. 9. sustainable transport biofuels have been discussed.

Two main approaches can be distinguished in the EU policy for sustainable transport biofuels, which are the quantity and quality approaches. The quantity approach has taken the form of interim and binding targets for the EU Member States in the question of renewable energy. The quantity approach has two central goals: the reduction of GHG emissions during the production of biofuels, with the purpose to maintain their sustainable quality, and a large scale production of sustainable biofuels inside EU. The quality approach is primarily expressed as the list of the sustainability criteria for biofuels. Internationally, it is a rather new issue in law, but its importance, especially in relation to the concepts of sustainable development and environmental sustainability, cannot be underestimated. It will be interesting to research in the future, whether there might be a conflict between the quantity and quality approaches in the EU policy for sustainable transport biofuels.

Conclusions can be made that the EU policy for sustainable transport biofuels is ambitious and motivating. It can be seen as an instructive example of how the concepts of sustainable development and sustainability can be legally operationalized and implemented. Directives 2009/28/EC and 2009/30/EC, as well as earlier documents, which have formed the EU policy in this area, have been important steps forward in the development of the EU approach to sustainable transport biofuels and their sustainable production. However, the interim indicative target for 2005 in Directive 2003/30/EC was not achieved by the majority of the EU Member States. It is questionable to what extent the binding 2020 targets from Directive 2009/28/EC will be achieved. The challenge is now to move from policy design to the implementation and enforcement of the requirements of Directive 2009/28/EC at the national level, with concrete actions on the ground. 113 If this is done successfully, Directive 2009/28/EC has the potential to become one of the most efficient legal frameworks on renewable energy in the world. 114

The EU policy for sustainable transport biofuels should be viewed as work in progress. There are many aspects that can be improved and/or made better organized. Preliminary, the set of the sustainability criteria for biofuels and control mechanisms for their fulfillment should be developed further. For example, criteria that regulate sustainable use of water and a tolerable use of fertilizes can be included.

Judging from the example of Directive 2009/28/EC, it can be summarized that a legal framework with binding environmental targets and mechanisms for their achievement should not necessarily be a goal of itself. It can be a part in the package of policy measures and instruments used to promote and safeguard environmental sustainability.

113 COM (2011) 31 final, Renewable Energy: Progressing towards the 2020 target, p. 14.

114 The European Solar Thermal Industry Federation (2013), RES Directive; SEC (2011) 129 final, Report on the operation of the mass balance verification method for the biofuels and bioliquids sustainability scheme in accordance with Article 18(2) of Directive, p. 2. 


\section{Acknowledgements}

I would like to thank the Law Faculty at Lund University, Sweden, and Vilhelm Persson, its Head, for providing extremely convenient research conditions. I would like to express my deep gratitude to Annika Nilsson, Karin Ericsson and Bengt Lundell, my research supervisors, for their guidance and useful critiques of the present research work. My special thanks are extended to the Johan and Jakob Söderberg Funding in Stockholm for its financial support.

\section{REFERENCES}

\section{Legal Sources}

[1] Directive $85 / 536 / \mathrm{EEC}$ on crude-oil savings through the use of substitute fuel components in petrol; is available at http://eur-lex.europa.eu/LexUriServ/LexUriServ.do?uri=CE LEX:31985L0536:EN:HTML, last visited 23-09-2013.

[2] Directive 2003/17/EC amending Directive 98/70/EC relating to the quality of petrol and diesel fuels; is available at http://eur-lex.europa.eu/LexUriServ/LexUriServ.do?uri=OJ: L:2003:076:0010:0019:EN:PDF, last visited 23-09-2013.

[3] Directive 2003/30/EC on the promotion of the use of biofuels or other renewable fuels for transport; is available at http://eur-lex.europa.eu/LexUriServ/LexUriServ.do?uri=OJ: L:2003:123:0042:0042:EN:PDF, last visited 23-09-2013.

[4] Directive 2009/28/EC on the promotion of the use of energy from renewable sources and amending and subsequently repealing

Directives 2001/77/EC and 2003/30/EC; is available at http:/ /eur-lex.europa.eu/LexUriServ/LexUriServ.do?uri=Oj:L:200 9:140:0016:0062:en:PDF, last visited 23-09-2013.

[5] Directive 2009/30/EC (on the quality of transport fuels) amending Directive $98 / 70 / \mathrm{EC}$ as regards the specification of petrol, diesel and gas-oil and introducing a mechanism to monitor and reduce greenhouse gas emissions and amending Council Directive 1999/32/EC as regards the specification of fuel used by inland waterway vessels and repealing Directive 93/12/EEC; is available at http://eur-lex.europa.eu/LexUriSe rv/LexUriServ.do?uri=OJ:L:2009:140:0088:0113:EN:PDF, last visited 23-09-2013.

\section{Policy Documents}

[6] COM (2006) 34 final, An EU Strategy for Biofuels, Communication from the Commission; is available athttp://eur-lex.europa.eu/LexUriServ/LexUriServ.do?uri=C OM:2006:0034:FIN:EN:PDF, last visited 23-09-2013.

[7] COM (2006) 545 final, Action Plan for Energy Efficiency: Realising the potential, Communication from the Commission; is available at http://ec.europa.eu/energy/action plan energy efficiency/doc/com 20060545 en.pdf, last visited 23-09-2013.

[8] COM (2006) 848 final, Renewable Energy Road Map.
Renewable energies in the $21^{\text {st }}$ century: building a more sustainable future,

Communication from the Commission; is available at http://e ur-lex.europa.eu/LexUriServ/LexUriServ.do?uri=COM:2006 :0848:FIN:EN:PDF, last visited 23-09-2013.

[9] COM (2007) 1 final, An Energy Policy for Europe, Communication from the Commission; is available at $\mathrm{http} / / /$ ec.europa.eu/energy/energy policy/doc/01 energy policy for europe en.pdf, last visited 23-09-2013.

[10] COM (2008) 30, 2020 by 2020 Europe's Climate Change Opportunity, Communication from the Commission; is available athttp://eur-lex.europa.eu/LexUriServ/LexUriServ. do?uri=COM:2008:0030:FIN:EN:PDF, last visited 23-09-2013.

[11] COM (2009) 192 final, The Renewable Energy Progress Report, Communication from the Commission; is available at http://eur-lex.europa.eu/LexUriServ/LexUriServ.do?uri=CO M:2009:0192:FIN:EN:PDF, last visited 23-09-2013.

[12] COM (2011) 31 final, Renewable Energy: Progressing towards the 2020 target, Communication from the Commission; is available at http://eur-lex.europa.eu/LexUriS erv/LexUriServ.do?uri=COM:2011:0031:FIN:EN:PDF， last visited 23-09-2013.

[13] Communication (2010/C 160/01) on voluntary schemes and default values in the EU biofuels and bioliquids sustainability scheme; is available athttp://ec.europa.eu/energy/renewables /biofuels/sustainability criteria en.htm, or athttp://europa.eu/rapid/pressReleasesAction.do?reference= $\mathrm{MEMO} / 10 / 247 \&$ format $=$ HTML\&aged $=0$ \&language $=\mathrm{EN} \& \mathrm{~g}$ uiLanguage $=$ en, last visited 27-12-2011.

[14] Communication (2010/C 160/02) on the practical implementation of the EU biofuels and bioliquids sustainability scheme and on counting rules for biofuels; is available at

http://ec.europa.eu/energy/renewables/biofuels/sustainability criteria en.htm, or at http://europa.eu/rapid/pressReleasesAct ion.do?reference $=\mathrm{MEMO} / 10 / 247 \&$ format $=$ HTML\&aged $=0$ \&language $=\mathrm{EN} \&$ guiLanguage $=\mathrm{en}$, last visited 27-12-2011.

[15] Council Regulation (EC) No 73/2009 establishing common rules for direct support schemes for farmers under the common agricultural policy and establishing certain support schemes for farmers, amending Regulations (EC) No 1290/2005, (EC) No 247/2006, (EC) No 378/2007 and repealing Regulation (EC) No 1782/2003; is available athttp://eur-lex.europa.eu/LexUriServ/LexUriServ.do?uri=O J:L:2009:030:0016:0016:EN:PDF, last visited 23-09-2013.

[16] Decision C (2010) 3751 on guidelines for the calculation of land carbon stocks; is available at http://ec.europa.eu/energy/renewable s/biofuels/sustainability criteria en.htm, or athttp://europa.eu/rapid/pressReleasesActi on.do?reference $=\mathrm{MEMO} / 10 / 247 \&$ format $=$ HTML\&aged $=0$ \& language $=\mathrm{EN} \&$ guiLanguage $=\mathrm{en}$, last visited 27-12-2011.

[17] European Commission (2009), IP/09/30, The Gas Coordination Group evaluates the current gas crisis and confirms measures to assist countries in need, Brussels, 9 January 2009, can be found at

http://europa.eu/rapid/press-release IP-09-30 en.htm, last visited 24-09-2013.

[18] European Commission, Mobility and Transport, Clean Urban Transport; is available athttp://ec.europa.eu/transport/urban/vehicles/road/road 
en.htm, last visited 21-08-2013.

[19] European Commission, Strategic Energy Technologies Information System SETIS (2013), Biofuels; ; is available at $\mathrm{http} / / /$ setis.ec.europa.eu/technologies/Biofuels/info, last visited 21-08-2013.

[20] SEC (2011) 129 final, Report on the operation of the mass balance verification method for the biofuels and bioliquids sustainability scheme in accordance with Article 18(2) of Directive, the EU Commission Staff Working Document; is available at

http://eur-lex.europa.eu/LexUriServ/LexUriServ.do?uri=SE C:2011:0129:FIN:EN:PDF, last visited 23-09-2013.

\section{Books, Articles and Dissertations}

[21] Afionis, S., Stringer, L. C. (2012). European Union leadership in biofuels regulation: Europe as a normative power? Journal of Cleaner Production, 32, 114-123, can be found at http://www.sciencedirect.com/science/article/pii/S09596526 12001825; last visited 07-11-2012.

[22] Associated Press in International Herald Tribune (2007), EU unveils plan to tackle oil and gas dependence, 09-01-2007, can be found at http://www.iht.com/articles/ap/2007/01/10/b usiness/EU-FIN-EU-Energy.php; last visited 14-01-2009.

[23] Biomass Technology Group, BTG (2008), Sustainability Criteria \& Certification Systems for Biomass Production, the final report, project No. 1386, the Netherlands, can be found a thttp://www.rpd-mohesr.com/uploads/custompages/sustain ability criteria and certification systems.pdf; last visited 22-08-2013.

[24] Börjesson, P., Ericsson, K., di Lucia, L., Nilsson, L., Åhman, M. (2008), Hållbara drivmedel - finns de?, rapport N. 66, November 2008, Lund University, Sweden; can be found at http://www.bilsweden.se/BinaryLoader.axd?OwnerID=2811 7958-207d-4842-aeeb-71ac13ef4c37\&OwnerType=0\&Prope rtyName $=$ Files\&FileName $=$ BILSwedenLU-hallbaradrivmed el.pdf, last visited 23-09-2013.

[25] De Alegría Mancisidor, I. M., Díaz de Basurto Uraga, P., Martínez de Alegría Mancisidor, I., \& Ruiz de Arbulo López, P. (2009). European Union's renewable energy sources and energy efficiency policy review: The Spanish perspective. Renewable and Sustainable Energy Reviews, 13(1), 100-114, can be found at

http://www.sciencedirect.com/science/article/pii/S13640321 07001165; last visited 23-09-2013.

[26] De Vita, A., de Coninck H., McLaren, J., Cochran, J. (2009), Climate for Collaboration: Analysis of US and EU Lessons and Opportunities in Energy and Climate Policy, a report, Energy research Centre of the Netherlands (ECN), can be found at http://nrelpubs.nrel.gov/Webtop/ws/nich/www/publ ic $/$ Record;jsessionid $=$ F668144CB39680AE3FF20CA581BE $\mathrm{A} 42 \mathrm{~F}$ ?rpp $=25 \& u p p=0 \& \mathrm{~m}=9 \& \mathrm{w}=\mathrm{NATIVE} \% 28 \% 27 \mathrm{AUTH}$ OR+ph+words+\%27\%27mclaren $\% 2 \mathrm{Bj} \% 27 \% 27 \% 27 \% 29 \& 0$ rder=native $\% 28 \% 27$ pubyear $\% 2$ FDescend $\% 27 \% 29$; last visited 07-11-2012.

[27] Di Lucia, L. (2013). Too difficult to govern? An assessment of the governability of transport biofuels in the EU. Energy Policy; can be found at http://www.sciencedirect.com/scienc e/article/pii/S0301421513008847\#, last visited 26-09-2013.

[28] Ebbesson J. (1996), Compatibility of International and
National Environmental Law, a dissertation, ISBN: 91-7678-320-0.

[29] ECORYS (2008), Assessment of non-cost barriers to renewable energy growth in EU Member States - AEON, a report, Rotterdam, the Netherlands; can be found at http://ec.europa.eu/energy/renewables/studies/doc/renewable $\mathrm{s} / 2010$ non cost barriers.pdf, last visited 21-08-2013.

[30] Gullberg, A., T. (2011), The European Union renewable directive: The policy-making process and the stakeholders' positions, in CICERO [Center for International Climate and Environmental Research] Working Papers 2011:02, September 2011, Oslo; can be found at http://www.cicero.uio.no/media/9115.pdf, last visited 21-08-2013.

[31] Haga, A., Rabben, J. (2010), Norway: EU Renewable Policy and Legislative Developments; can be found at http://www.mondaq.com/article.asp?articleid=92402, last visited 21-08-2013.

[32] Hoogeveen, J., Faurès, J. M., \& Van De Giessen, N. (2009). Increased biofuel production in the coming decade: to what extent will it affect global freshwater resources?. Irrigation and Drainage, 58(S1), S148-S160; can be found athttp://onlinelibrary.wiley.com/doi/10.1002/ird.479/full, last visited 23-09-2013.

[33] Howes T. (2010), Directive 2009/28/EC, in Oberthur, S., Pallemaerts, M. (edits.), 2010, The New Climate Policies of the European Union: Internal Legislation and Climate Diplomacy, Institute for European Studies, Brussels University Press.

[34] Jansen, J, Uyterlinde, M. (2004), A fragmented market on the way to harmonisation? EU policy-making on renewable energy promotion, Energy for Sustainable Development, March 2004, vol. 8, issue 1, pp. 93-107; can be found at http://www.sciencedirect.com/science/article/pii/S09730826 08603944, last visited 21-08-2013.

[35] Kanellakis, M., Martinopoulos, G., \& Zachariadis, T. (2013). European energy policy A review. Energy Policy, can be found at http://ac.els-cdn.com/S030142151300801X/1-s2.0-S030142 151300801X-main.pdf? tid=936aa156-251e-11e3-93fc-00000aacb362 \&acdnat $=1380$ 030080 67bfade77f5633203292be8111c9ccc7; last visited 24-09-2013

[36] Lucia D., L., Nilsson, L., J. (2007), Transport biofuels in the European Union: The state of play, Transport Policy, November 2007, vol. 14, issue 6, pp. 533-543; can be found at http://ac.els-cdn.com/S0967070X07000790/1-s2.0-S096707 0X07000790-main.pdf? tid=ed3d82ba-0a49-1 1e3-8da9-00000aab0f26\&acdnat=1377 080018 dc02f05252222abf3aa6f978c86e2340, last visited 21-08-2013.

[37] Majer, S., Mueller-Langer, F., Zeller, V., Kaltschmitt, M. (2009), Implications of biodiesel production and utilization on global climate A literature review, European Journal of Lipid Science and Technology, August 2009, vol. 111, issue 8, no. 8, pp. $747 \quad-762$; can be found at http://onlinelibrary.wiley.com/doi/10.1002/ejlt.200900045/a bstract, last visited 21-08-2013.

[38] Ryan, L., Convery, F., Ferreira, S. (2006), Stimulating the Use of Biofuels in the European Union: Implications for Climate Change Policy, Energy Policy, November 2006, vol. 
34, issue 17, pp. 3184-3194; can be found athttp://ac.els-cdn.com/S0301421505001655/1-s2.0-S03014 21505001655-main.pdf?

id=aef575aa-0a47-11e3-994d-00000aab0f02\&acdnat $=13770$ $79054 \mathrm{c} 07 \mathrm{f} 09 \mathrm{c} 49 \mathrm{~d} 2444 \mathrm{f} 70 \mathrm{c} 735052723 \mathrm{c} 57 \mathrm{ff}$, last visited 21-08-2013.

[39] Scarlat, N., Dallemand, J. F., \& Banja, M. (2013). Possible impact of 2020 bioenergy targets on European Union land use. A scenario-based assessment from national renewable energy action plans proposals. Renewable and Sustainable Energy Reviews, 18, 595-606; can be found at http://www.sciencedirect.com/science/article/pii/S13640321 12005916, last visited 26-09-2013.

[40] Schlegel, S., Kaphengst, T. (2007), European Union Policy on Bioenergy and the Role of Sustainability Criteria and Certification Systems; Journal of Agricultural \& Food Industrial Organization, 2007, vol. 5, article 7; can be found at the Berkeley Electronic Press, http://ecologic.eu/duke/downl oad/JAIFO bioenergy.pdf, last visited 05-04-2012.

[41] The Engineer (2007), 03-09-2007, an article, can be found at http://proquest.umi.com/pqdlink?Ver=1\&Exp=10-26-2008\& REQ $=1 \&$ Cert $=1$ Xu3PbBnxTzlrF7ZLHL04vTPSFbjpPSRoP0 qt7habI9jgm9Yq4qrPKI\%2fi9WCStP1\&DID=1331082391; last visited 14-01-2009.

[42] The European Federation for Transport and Environment (2008), EU spending $€ 1$ billion a day on oil imports as leaders backtrack on efficient cars, Briefing, 18-06-2008, can be found at

[43] www.transportenvironment.org/Publications/prep hand out/lid:505; last visited 14-01-2009.

[44] The European Solar Thermal Industry Federation (2013), RES Directive, can be found at http://www.estif.org/policies/ res directive/; last visited 23-09-2013.

[45] The Heritage Foundation (2007), Europe's Strategic Dependence on Russian Energy, 05-11-2007, can be found at http://www.heritage.org/Research/Europe/bg2083.cfm; last visited 14-01-2008.

[46] Westerlund, S. (2003), Miljörättsliga grundfrågor 2.0, Institutet för miljörätt (IMIR), Björklinge.

\section{Internet Sources}

[47] The European Biofuels Technology Platform, http://www.biofuelstp.eu/; last visited 23-09-2013.

[48] The EU Commission, Biofuels, Sustainability Criteria http://ec.europa.eu/energy/renewables/biofuels/sustainability criteria en.htm; last visited 24-09-2013.

[49] The EU Commission Transparency Platform http://ec.europa.eu/energy/renewables/transparency platform/transparency platform en.htm; last visited 23-09-2013. 